\title{
Farmer Group Performance of Collective Chili Marketing on Sandy Land Area of Yogyakarta Province Indonesia
}

\author{
Alia Bihrajihant Raya ${ }^{1,2}$ \\ ${ }^{1}$ Department of Agriculture and Resource Economics, Graduate School of Agriculture and Life Sciences, The \\ University of Tokyo, 1-1-1 Yayoi, Bunkyo-ku, Tokyo, Japan \\ ${ }^{2}$ Department of Socio-economics of Agriculture, Faculty of Agriculture, Gadjah Mada University, Indonesia \\ Correspondence: Alia Bihrajihant Raya, Department of Socio-economics of Agriculture, Faculty of Agriculture, \\ Gadjah Mada University, Jl Flora 1 Bulaksumur, 55281 Yogyakarta, Indonesia. E-mail: \\ dirayakan@faperta.ugm.ac.id
}

Received: December 20, 2013 Accepted: March 17, 2014 Online Published: April 29, 2014

doi:10.5539/ass.v10n10p1 URL: http://dx.doi.org/10.5539/ass.v10n10p1

\begin{abstract}
The aim of this research is to examine the relationship between both individual background and performance of collective actions in relation to the different forms of collective marketing. This research measured the two pioneering farmer groups who successfully carried out collective marketing. The percentages of collective marketing are similarly obtained by each group, but the rules for carrying out collective marketing differ. The individual background and performance of collective actions other than collective marketing among members should be considered to describe the different forms of collective marketing. A total of 120 members were interviewed from the two farmer groups that were chosen by stratified land cultivating area and random sampling. Performance of collective action was measured through the attitude toward selling chilies and the effort to find the seeds and labor sources. Next, all data were analyzed by multiple regression analysis. The result indicated that percentage of selling on collective marketing on Bugel is influenced by age and possibility on buying seed collectively through the group, off-farm job and plastic application. However, the difference result is appeared on Garongan farmer group, received remittance, conducted custom help labor and utilizing non-subsidized fertilizer are influences the percentage of selling chili on collective marketing. In Bugel's farmer group, farmer with stable off-farm income who behave opportunistically in terms of collective marketing tend to hold the power and drive the group performance loosely organized. Garongan's farmers respect the norms of collective action to achieve purposes that keeping the organization tightly and functioning smoothly.
\end{abstract}

Keywords: farmer group, collective marketing, chili farming

\section{Introduction}

In Indonesia, there are more than 300 thousand farmer groups, which are located in 33 provinces and 70 thousand villages while in Yogyakarta Province around 5 thousand farmer group are existing on 2012 (Agriculture research center, 2012). Farmer groups were initiated in the 1970s to strengthen the bargaining position of farmers. These groups bargained collectively for such features as subsidized fertilizer, capital aid from the government, shared information among members, and receipt of information from extension agents. Since 1997, government through Agriculture Minister Decree 273/Kpts/OT.160/4/2007 has been broadening the function of farmer group as an economic unit to increase the marketing ability in the farmer group. Recently, a few farmer groups have begun collective marketing to create marketing chains and develop bargaining power in selling products.

Since 1985, farmers who are surrounded by coastal areas in Yogyakarta Province have been cultivating chilies. This effort was initiated by two villages in Bugel and Garongan. Marginal land, extreme climates and the need to access information forced them to create a farmer group. Collective marketing, an invention of farmer groups, has been implemented for the past ten years and has provided a good price and profit for the members, creating better economic conditions for the poor farmers.

Farmer groups have been built on the basis of the communities in which they were formed. As a result, societal norms and rules are the basis for regulating the attitude and behavior of members in achieving the group's 
purposes. All members as individuals perform based on calculated costs and benefits which include the area's economy, social, and psychological concerns. The members adjust their behavior when the group cannot facilitate the social network and economic exchange to provide satisfactory conditions. Farmers can decide to work collectively or individually, considering their preferences and values, in order to maximize economic and societal benefits. Social ostracism and sanctions enforce the obeying of societal rules. On the contrary, individual members who have power lead the group with authority. As a result, the characteristics of collective action on farmer groups differ depending upon who leads the particular group.

This study measured the two pioneering farmer groups who successfully carried out collective marketing. These groups are located in sandy land areas in villages near each other. Approximately $90 \%$ of Bugel's and $95 \%$ of Garongan's total chili production was sold via collective marketing in 2011. The percentages of collective marketing are similarly obtained by each group, but the rules for carrying out collective marketing differ. The individual background and performance of collective actions other than collective marketing among members should be considered to describe the different forms of collective marketing. Therefore, the primary aim of this research is to examine the relationship between both individual background and performance of collective actions in relation to the different forms of collective marketing.

\section{Literature Review}

In Indonesia, chillies are a priority crop mostly produced by smallholder farmers. It becomes an important cash flow income for them which are mainly sold in domestic markets to wholesaler, retail fresh market, food processors and supermarkets. The traditional markets (into wholesaler and retailer) channel dominates approximately $95 \%$ of chili marketing in Indonesia (White, Morey, Natawidjaja, \& Morgan, 2007). The wholesaler trader set chili prices based on the daily situation of demand and supply of chillies in these markets. Farmers are not able to do something to change increase the absolute chili price in the markets when there is an oversupply of chili product. Ironically, the price on the intermediate trader will be much lower price (Fafchamps \& Vargas-Hill, 2005). Therefore, developing a good relationship with the wholesale traders will bring a good opportunity for farmer because farmer are able to accept correct price information, price transparency and good price quality ratio (Sahara, Gyau, Stringer, \& Umberger, 2013).

Accessing the market now plays the important role to eradicating the poverty in rural area. When rural producers were able to organize themselves, gain access to up-to-date market information and better rural roads to help reduce transaction costs, the market would become a powerful ally in the effort to end poverty (IFAD, 2001). Producers groups can ease long marketing chains by connecting smallholder farmers directly to markets through passing all kinds of market intermediaries (Markelova \& Meinzen-Dick, 2009). Farmer group in Indonesia could be able to take an important role in order to cut some intermediaries of selling chillies and strengthen the position of the group to establish the network with wholesale traders.

Meanwhile, according to Wahyuni (2005), most of farmer groups in Indonesia are play roles of helping members determine and supply the input for producing the products, channeling the capital loan, and processing the output. Farmers who are not part of a farmer group will face difficulty in gaining input subsidies or capital funds. Even though Fox (1979) emphasized that group of farmers whose work involves marketing activities improve the economic conditions.

Furthermore, farmer groups are a social institution, which influence people and have a significant effect on determining the social consensus and values imposed upon them by society (Gordon, 1980). Individual members are under consensus forces to conform and to behave in the ways of institutional norms. Scott described that everyone in the community are alike and all member of the community should be supported by the elites (Little, 2011). As a result, groups shape the patterns of human interaction and the results that individuals achieve (Pradhan, 1999). To the contrary, Popkin (1980) determined that norms are malleable, renegotiated and influenced by power and strategic interaction among individuals. In regard to the inconsistencies and conflicts among norms, farmers tend to choose private insurance or welfare. Farmers consider contributing to the group by calculations among costs and benefits. Popkin (1980) argued that individual farmers are not only concerned with material and financial income, but also the rationale for evaluating the possible outcomes associated with their preferences and values.

The above literature and several previous articles emphasize that there is dichotomy that explain collective behaviors of farmers by moral economy and rational farmer theories. However, the research should combine both theories to explain individual factors and the performance of collective actions that generate the different forms of collective marketing in the two neighboring villages, Bugel and Garongan. These villages share local norms in term of chili farming; however, the management of collective marketing is different, so that not only 
the moral economy, but also the individual situations should be taken into consideration simultaneously. Supriyanto et al., (2012) found that community capital including physical, social, human, economic, and politic capital has existed and been contributed to successful collective actions in two neighboring farmer groups, but they disregard the different management of collective marketing.

Some literatures pointed out the factors which influence the activities of collective marketing. A research regarding participation in yam collective marketing in Nigeria found that participation of collective marketing was influenced by the distance of the nearest market, household size, farm size, revenue from yam sales, access to the market, access to credit facilities, hiring of farm labor, transportation cost and membership of cooperatives (Cecillia, Victor, Blaise, Omobowahe, \& Abayomi, 2009). Lapar, Holloway, \& Ehui (2003) further indicated that education and alternative employment opportunities were of significant impact in collective marketing participation. In addition Markelova and Meinzen-Dick (2009) summaries three important factors of farmer group due to succeed on collective marketing, such as 1) characteristics of product and market, characteristic of agriculture product develops the different ways to market it. Actually there are three main categories of product: staples, perishables and cash crops. Staples are relative easy to store and transport but there are not be a high incentive to manage collective marketing. Perishables are high risk and require a good storage and good transportation so that individual farmer probably will not able to handle individually because of lack capital and knowledge; there is an opportunity to market collectively. Cash crops require further processing so individual farmer has no opportunity to sell the product directly to the market. 2) characteristic of group is enabling factor to success on collective marketing, the group which has same socio economics status, shared norms and value, knowledgeable leader and trusted by member and 3) group arrangement or rules is needed to develop accountability and enforcement mechanism.

This study contributes to the literature. First, this study attempts to clarify the different individual background of farmer determine join collective marketing under the different forms of collective marketing. Second, this study emphasized that chili collective marketing in Indonesia, is one of problem solving, to bear the intermediate traders which control the chili price much lower than wholesale trader's price which disadvantages to the farmers.

\section{Method}

Data were collected on the history of sandy land cultivation, demographic characteristics, socioeconomic conditions, chili production. Furthermore, information was gathered on gaining access to input, getting labor and marketing chili collectively. A field survey was conducted to obtain primary data from Bugel and Garongan farmers' groups in Yogyakarta Province. Sixty heads of farming households from a total of 94 farmer group members were selected from Bugel and 60 household farmers from a total of 85 group members were selected from Garongan to be interviewed. A total of 120 members were interviewed from the two farmer groups that were chosen by stratified land cultivating area and random sampling. The interviews were conducted using a questionnaire.

Individual opportunistic behavior could influence the management of the institution. In order to seek this information, individual factors and performance of collective action were collected. In terms of individual factors, demographic data such as age and educational level was recorded. To understand the socioeconomic conditions, data on the economic structure, such as agricultural revenue and expenditures, alternative income sources such as off-farm job and remittance, and the determination as to whether to apply non-subsidized fertilizer and plastic on chili farming were measured by the questionnaire. Performance of collective action was measured through the attitude toward selling chilies and the effort to find the seeds and labor sources.

Performance of collective marketing is measured through the percentage of the amount of chili selling collectively from total production (Y). There are nine independent variables: age (X1), education (X2), received remittance (X3), engaged off-farm job (X4), utilizing custom help labor (X5), utilizing non-subsidized fertilizer (X6), applied plastic to cover sandy land (X7), using seed from collective buying (X8) and chili revenue (X10). To examine how multiple independent variables related to the dependent variable, so that multiple regressions were functioned to get a best prediction on performance of collective marketing. Each data of Bugel and Garongan was analyzed separately and compared.

\section{Characteristics of Farmer Groups on Sandy Land Areas}

In the west region of Yogyakarta Province, there are three types of areas, which are categorized by highland, hilly and lowland terrains. Lowland areas have a sandy land, which is $22 \mathrm{~km}$ long, $1.8 \mathrm{~km}$ wide and covers 3000 ha of sandy land area. Farmers started to cultivate this sandy land prior to 1970, but they could only cultivate based on rainfeed. Only a few farmers who possessed irrigated paddy field could cultivate paddies. Garongan's 
farmers possessed less irrigated paddy field than Bugel's farmers.

Chili farming is a new farming system in sandy land that introduced the 1980s. The innovation appeared when a farmer determined that the chili could grow in sandy land during the rainy season; furthermore, it could also grow during the dry season by building a well to supply fresh water. After introducing chili farming in 1980, farmers created a farmer group in 1985. The activities of farmer groups included land arrangement, land clearing, building impermanent roads and uniting farmers for problem solving. The extreme climate included high temperatures and strong winds that affected the emergence of disease forced farmers to organize a planting pattern. Starting in 1990, new planting patterns became a basic rule of both groups because breaking the rule of planting pattern would break the ecosystem condition of sandy land.

Farmer living in those villages can become members of the farmer group evenly whereas all chili farmers are member of farmer group in each village. Member had no pressure imposed upon them to pay for a membership fee. Moreover, farmer group in Bugel and Garongan has also facilitated members in order to buy input collectively. They have been initiated to cooperate with the input provider or input distributor. In case of seed collective buying, Bugel and Garongan have cooperated with seed distributor but in case of subsidized fertilizer only Garongan farmer group has cooperated with input trader. While nearly $70 \%$ of farmer groups in Indonesia had taken part only in channeling subsidy from the government, but Bugel's and Garongan's farmer groups took this one step further and began to market the chili fresh product. This was the result of a problem that arose in that chilies are a perishable stock, and the prices tend to fluctuate.

Regarding chili trading activities, there are four hierarchical categories of chili trading such as wholesale trader, assembler trader, intermediate trader and sub-intermediate trader. In Garongan village, there are three sub-intermediate traders appeared on the chili trading activities which are also member of Garongan farmer group and one assembler trader who is transporting fresh chili from this area to capital city. Meanwhile, there is only one intermediate trader in Bugel village which is also deal as input provider for Bugel farmer. The input provider of Garongan farmer is different from chili trader because assembler trader are busy to make effort on transporting chili while sub-intermediate trader has not enough capital to deal as input provider.

Collective marketing has been initiated by Garongan Farmer Group when the different price of chili product among farmers brings out the social problem. Sub-intermediate trader works for intermediate trader while intermediate traders determined capacity buying of sub-intermediate traders. When they cannot fulfill target of quota, they will eagerly buy a chili product with a high price, but they also can make the price down when the quota is satisfied. Among farmers who sell chili in the same sub-intermediate traders with different price they criticized each other. Farmers also criticized sub-intermediate traders about the way of buying their chili product. Then, Garongan farmer group emphasized the importance of social group on conducting chili farming so the price gap among farmers should have been resolved it. In this matter, each farmer should receive same price on selling chili while each farmer also should sell same percentage of chili in collective marketing. Determining the minimum percentage of selling chili oncollective marketing has a purpose to gain a high and stable price during the harvesting period. As follower, Bugel farmer group, has been imitated its marketing mechanism without determined the minimum percentage of selling chili because Bugel farmer group believes that farmer will rationally choose collective marketing which is always provide a high price comparing another trader.

The activity of collective chili marketing has attracted assembler trader from many areas and distributes them to a wholesaler in Jakarta, Java and Sumatera Island,assembler traders purchase chilies directly through the group. Moreover, through collective marketing, every farmer can contribute to the group 150 IDR per kilogram chili that is sold via collective marketing. From that contribution, one-third goes for committee member's fees; one-third goes toward group capital for seed, and one-third goes directly to the farmer group. After ten years of operating under collective marketing, the group collected as much as 25 million IDR in Garongan and Bugel's farmer group possesses 35 million IDR. This is used to buy seed collectively.

Mechanism of functioning the fund for buying seed collectively is different in each village. Garongan farmer group accumulates the fund to buy some packages of seed which then is distributed equally using two rounds of distribution. During the first round, the Garongan farmer group distributed seed equally regardless the land area while in second round, the distribution was based on the proportion of seed available and the land area cultivation. In other hand, Bugel farmer group uses the fund to buy some package of seed which is distributed to the member in sequence considering of keeping big fund to small fund contribution from previous collective marketing.

\section{Results and Discussion}

\subsection{Socioeconomic Characteristics of Farmers in Farmer Groups}


The characteristics of farmers from Bugel and Garongan differ according to age, sex, education, cultivating land, on-farm income, and off-farm income. In Bugel, the majority of household head farmers (67\%) completed senior high school; in contrast, the majority of household head farmers in Garongan only finished junior high school. Furthermore, $10 \%$ of Bugel's household head farmer graduated from college.

Bugel's farmer households cultivated 0.43 ha of land on an average, and Garongan's farmer households cultivated 0.49 ha respectively. Around 0.32 ha sandy land is cultivating by Bugel farmer household, 0.05 ha in irrigated paddy fields and 0.06 ha in home gardens. Garongan's farmer household is tilling 0.35 ha sandy land, 0.07 ha irrigated paddy fields and 0.07 ha home gardens. Before the intensive cultivation of sandy land on 1980, some Bugel farmers who possessed larger irrigated paddy field had relatively prosperous lives. They could afford to send their children to high school, and their children could have an opportunity to obtain off-farm jobs. Nowadays, the condition of possessing irrigated paddy field has been reversed; Garongan are cultivating larger irrigated paddy field than Bugel's because some Garongan farmers, who were motivated to produce paddies to support their self-sufficiency of rice, tried to buy irrigated paddy field on the surrounding village.

Albeit the on-farm income in Garongan is higher than in Bugel, but off-farm income is reversed. This difference was triggered by prior economic conditions in the two villages. Bugel farmers' off-farm contributed to income as much as $38 \%$ of their total income but Garongan farmers only contributed $12 \%$. Having an off-farm job and receiving remittance from a family who is working outside contributed highly to the economic structure of the Bugel farmer. Garongan farmers also received remittance from family members who worked outside, but it was very limited. Table 1 shows that on Bugel's sandy land, chili production contributed $61 \%$ and watermelon $21 \%$ to their revenue. Bugel farmers extended the period of chili planting from March until November, they could produce more chilies. Garongan farmers, however, did not extend the chili planting pattern and changed to watermelon in October. As a result watermelon contributed $36 \%$ and chili $48 \%$ to their revenue. In sandy land, both farmers from Bugel and Garongan usually planted chilies and watermelons alternately as a main commodity which is regulated under the consensus.

Table 1. Economic structure of Bugel's and Garongan's household farmers

\begin{tabular}{lllll}
\hline Dimension & $\begin{array}{l}\text { Bugel } \\
\text { IDR (000) }\end{array}$ & $\mathbf{\%}$ & $\begin{array}{l}\text { Garongan } \\
\text { IDR (000) }\end{array}$ & \% \\
\hline Sandy land & & & & 48 \\
Chillies & 20,924 & 61 & 29,349 & 36 \\
Watermelon & 7,384 & 21 & 13,393 & 10 \\
Other & 5,002 & 14 & 4,560 & \\
Irrigated Paddy Field & & & & 6 \\
Paddy & 3,139 & 4 & 1,709 & $\mathbf{1 0 0}$ \\
Agric Revenue (A) & $\mathbf{3 6 , 4 4 9}$ & $\mathbf{1 0 0}$ & $\mathbf{4 9 , 0 1 0}$ & 12 \\
Seed & 2,191 & 11 & 2,741 & 14 \\
Pesticide & 1,638 & 8 & 2,887 & 34 \\
Fertilizer & 5,665 & 28 & 7,601 & 2 \\
Plastic & 529 & 3 & 486 & 17 \\
Hired Labor & 6,443 & 32 & 3,847 & 21 \\
Other & 3,672 & 18 & 4,656 & $\mathbf{1 0 0}$ \\
Agric Expenditure (B) & $\mathbf{2 0 , 1 3 8}$ & $\mathbf{1 0 0}$ & $\mathbf{2 2 , 2 1 9}$ & \\
Agric Income (A-B=C) & $\mathbf{1 6 , 3 1 1}$ & & $\mathbf{2 6 , 7 9 2}$ & \\
\hline
\end{tabular}

Source: Primary Data Analysis, 2013

* $1 \mathrm{USD}=8,500$ IDR (2011)

The consensus of the group was for the farmer to start planting chilies by March and then change to other commodities in September. However there was a difference in the consensus between the two groups. Garongan's farmer group strictly implemented the planting pattern. All farmers who cultivate on sandy land area either farmer from inside the village or outsider farmers should follow the planting pattern rules. Farmer groups could give sanctions for disobedient farmer by revoking the plants. However, started on 2011 farmers in Bugel 
were allowed to extend the period of chili planting. There are two phenomenon which triggered the permission of extension of planting patterns in Bugel, price and plastic. On 2011, the chili price was decreased on the 3000 IDR while on 2010 chili price reached out to 30000 IDR per $\mathrm{kg}$. Then, some farmers tried to extent the period of harvesting in order to reach a higher price. Starting this moment, the planting duration is not being organized collectively by farmer group anymore which means every farmer is able to start and finish chili farming based on his own willingness. Moreover, they believed that climate barriers could solve through applying plastic. Yet, they were not recognized that plant rotation is important to prevent virus from spread up especially on sandy land area when the wind blows strongly. As a result, on 2012, many chili plants on Bugel were infected with yellow virus.

Table 2. Non-agricultural income and total income of farmers in Bugel and Garongan

\begin{tabular}{lllll}
\hline Dimension & $\begin{array}{l}\text { Bugel } \\
\text { IDR (000) }\end{array}$ & HH & $\begin{array}{l}\text { Garongan } \\
\text { IDR (000) }\end{array}$ & HH \\
\hline Agric Income (C) & $\mathbf{1 6 , 3 1 1}$ & & $\mathbf{2 6 , 7 9 2}$ & \\
1. Off-Farm Job & 4,049 & & 1,545 & 6 \\
a. Agric Labor & 265 & 12 & 148 & 2 \\
b. Construction Labor & 850 & 7 & 122 & 3 \\
c. Chili Trader & 600 & 1 & 393 & 4 \\
d. Non Chili Trader & 1,241 & 5 & 686 & 0 \\
e. Fisherman & 168 & 2 & - & 6 \\
f. Government Officer & 925 & 4 & 196 & 334 \\
2. Remittance & 2,734 & 17 & $\mathbf{1 , 8 7 9}$ & $\mathbf{2 8 , 6 7 1}$ \\
Non-Agric Income (D) & $\mathbf{6 , 7 8 3}$ & & & \\
Total Income (C+D=E) & $\mathbf{2 3 , 0 9 4}$ & & & \\
\hline
\end{tabular}

Source: Primary Data Analysis, 2013

Table 2 shows the different variety of off-farm job and amount of remittance for farmers in Bugel and Garongan's farmer group. Agricultural labor in Bugel is an alternative job for some farmers because some farmers will seek hired agricultural labor for weeding and harvesting while on Garongan has been functioning traditional custom help labor which is called sambatan. In addition, the different educational background has influenced the opportunity to get an off-farm job as construction labor and government officer. Some construction project and government job vacancy only would employ the high educational background person so that some Bugel farmers possessed opportunity to become construction labor or government officer than Garongan farmers. However, in Garongan village, farmers faced the lack opportunity to go outside village for work then they created off-farm job like chili trader and other product. Even though, collective marketing has established but Garongan farmer group's board gave permission for chili trader to collect some chilies from farmers while Bugel farmers has not interested to become chili trader because they hold various opportunity to work outsides.

Possessed irrigated paddy field in the past ushered Bugel farmers having a good education while armed with good education helped them earn more money rather than Garongan farmers which it was used to send their descent to high school. Moreover, the generation of Bugel farmers also possessed the high educational background and they could seek job outside village. As a result, Bugel farmer's descents could send more remittance to their family.

\subsection{Collective Action of Chili Farming and Marketing}

Until 2002, farmers in Bugel and Garongan used local varieties of chilies, but local seed was susceptible to disease. Farmers then changed to hybrid chili seed, which was made available by a seed factory. In order to help members find cheaper seed, both farmer groups established a partnership with the seed factory distributor through collective buying. Collective buying forced prices down, but usually distributors could not meet the large amount needed by the farmer groups.

In Bugel, distribution of seed collective buying was based on first-come, first-served policy. Seed availability was shared first with those farmers who had savings on the account of farmer group funds. Therefore, farmers 
who did not sell such quantities did not have much opportunity to get sufficient seed. Garongan farmer's group set up the different consensus of seed distribution. Groups determined that each farmer have a same chance to get seed equally. During the first round, the Garongan farmer groups distributed equal amount of seed regardless land area for all members. In the second round, the distribution was based on the proportion of seed available and the land cultivation; only those members who needed more seed could buy individually. Despite the equal distribution, which seems to disserve the larger land areas, the moral perspective on helping each other became a motivation among them.

In Indonesia, there are two types of fertilizer, government subsidized and non-subsidized. Subsidized fertilizer is distributed differently in Garongan than in Bugel. In Bugel, the authorized subsidized fertilizer agent is located near village, allowing members to freely buy their own subsidized fertilizer without going through farmer groups. By comparison, Garongan's authorized subsidized agent cannot make subsidized fertilizer available individually whenever it is needed. More or less ten farmers should reserve in advance then the agent will provide subsidized fertilizer. Garongan's farmer realized that the more member reserved the quicker subsidized fertilizer will get. This problem has initiated the Garongan farmer group to start collective buying for subsidized fertilizer. The group is listing the farmer who wants to buy it, and then farmer should pay the price in advance immediately. Garongan farmer group buys the subsidized fertilizer from the authorized agent and then distributes it to the group members. In case of non-subsidized fertilizer, farmers of Garongan and Bugel are able to buy freely through the shop.

Harvesting is the busiest period of chili farming. Chili can be harvested 15-20 times in one season. In the peak harvesting season, farmers in Bugel and Garongan look for hired harvesting labor. The cost of harvesting labor can be as high as 25,000-30,000 IDR per person for eight hours a day. Some Garongan farmers can arrange sambatan among their neighbors or relatives instead of hiring labors. This reduces the cost because sambatan is a mutual help system which every member should exchange labor among small group members without pay for the work.

Applying plastic which covered the surface of land replaces the need for weeding labor. Although using plastic reduces labor costs, the farmer needs additional expenditure, because plastic must be purchased before the initial planting time. In 2011, only 17\% of Garongan farmers applied plastic, whereas $37 \%$ of Bugel farmers used plastic. Using plastic is very helpful for Bugel farmer because they are not only busy with chili farming but also busy with off-farm job. In addition, applying plastic makes farmers more independent from others, as they do not need labor assistance for weeding.

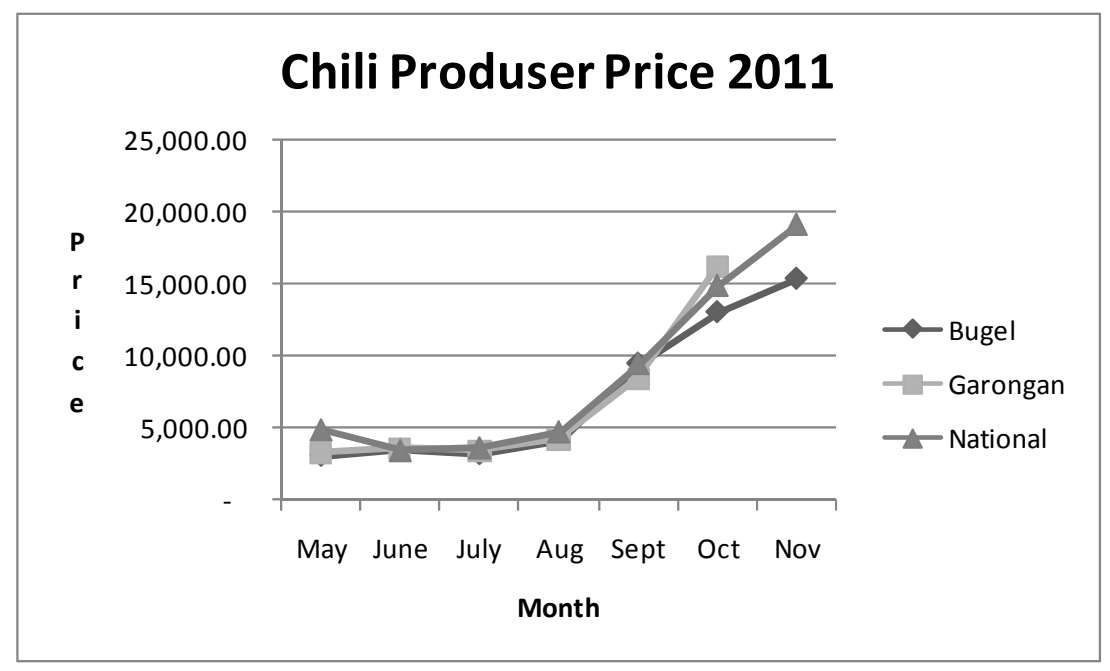

Figure 1. Producer price comparison between Group and National Level in 2011

Source: Bugel and Garongan Farmer Group Financial Report, 2011 (calculated, 2013) and Indonesia Economic Observation 2011-2012, Indonesia Ministry for Economy Affairs

Furthermore, collective marketing has strengthened the bargaining power of farmers to sell chili products. In the past, farmers sold chilies individually to intermediate traders. After farmer groups began collective marketing, traders who desired to buy chili products from that village had to buy chili through the group. Then, auction has 
been chosen as a system to selling collective chili product to traders. Traders who joined as auctioneer were assembler trader which comes not only from the surrounding area but also other cities in Central Java. The price at the auction was influenced by the national price of wholesalers in Jakarta, the capital city. Figure 1 shows that producer prices at a group level coincide with the national producer price. According to trader, prices in production areas are much lower around three-fourth of chili price than those of the wholesaler but in those villages the price of chili product has only slightly different with the producer price on national level. The capability of maintaining high chili price on each harvesting season motivates the farmers to keep selling through collective marketing.

One disadvantage of selling chilies at the collective marketing in both groups is delayed payment by three days or more. Trader who win the auction requests the procrastination of payment until the product has assembled in the wholesaler in capital city which minimally three days after transported chili product. In term of collective marketing, both farmer groups succeed to stabilized chili price among the farmers but the payment system of chili product has still hold by traders, which means farmers and farmer groups have encoutered the delay payment problem.

\subsection{Factors of Individual Performance for Collective Marketing}

Performance of collective marketing is measured by the percentage of the amount of chili selling collectively from total production. Bugel's farmer group does not arrange the minimum chili product collection, but Garongan's farmer group has determined at least $80 \%$ of total production should sell via collective marketing. Both groups can reach average percentage on collective marketing but the individual performance on product collection is different. In Garongan's farmer group, they collect maximally $100 \%$ and minimally $67 \%$, but Bugel's farmers collect maximally $100 \%$ and minimally $0 \%$. In both groups, only a few farmers sold exceptionally small percentage through collective marketing. In the case of Garongan, as exceptional case there are four farmers which sell $67 \%, 67 \%, 71 \%$ and $75 \%$ through collective marketing. Among those four farmers, three farmers are sub-intermediate trader and one farmer is brother in law of sub-intermediate trader. Their chili trading activity is under management of intermediate trader which determined the capacity of buying for them. After collecting marketing has begun, the sub-intermediate trader is difficult to fill up the quota of buying because they are not auctioneer so that they should cover the shortage of chili product by using their own chili product. In Bugel, there are four exceptional farmers who sold chili $0 \%, 33 \%, 43 \%$ and $43 \%$ through collective marketing. Those farmers are old farmers, who possessed an off-farm job like construction labor and government officer, they do not work hard for chili farming because of their off-farm job business. After excluded the farmers, 56 farmers from Garongan and 56 farmers from Bugel are observed sold chili more than $80 \%$ of their total product to collective marketing.

Even though the farmer groups are located nearby villages but they developed the different management of farmer groups. Garongan farmer group has been functioning meeting to spread up the information to all members of farmer group. The meeting is held every 35 days routinely. In this sense, member will become well-informed because of the existence of meeting. In here, farmer group is sought to support all farmers equally. Moreover, farmers should obey the consensus and regulation from the Garongan farmer group while the social ostracism will occur when they are disobeying it. Farmer who did not attend the routine meeting will ostracize from custom help (sambatan) while farmer who disobey the planting duration, will accept sanction by revoke the chili plants.

Bugel farmer group has also determined the routine meeting when it had developed but sooner they decided the interpersonal communication for delivering the message. It is triggered by the busy farmers, who have an off-farm job, they could not attend the meeting without being ostracized. As a result, interpersonal communication has developed stronger than group meeting. Furthermore, some farmers have a possibility to miss the useful information when they cannot initiate interpersonal communication. For farmers whose missing the information, they should resort to third party like trader for surviving on conducting chili farming. Bugel farmers become more independent from farmer group and opportunistically decide whether they participate totally on group or utilize the function of farmer group along with other party favorably. As a result, some Bugel farmers maintain close relationship with trader to secure their need such as scarcity of seed and uncertain chili market. 
Table 3. Multiple regression of collective marketing on farmers groups in Bugel and Garongan

\begin{tabular}{|c|c|c|c|c|}
\hline \multirow{3}{*}{ Variable } & \multicolumn{4}{|c|}{ Dependent variable } \\
\hline & \multicolumn{2}{|c|}{$\begin{array}{l}\text { Percentage of Collective Marketing } \\
\text { in Bugel }\end{array}$} & \multicolumn{2}{|c|}{$\begin{array}{l}\text { Percentage of Collective Marketing in } \\
\text { Garongan }\end{array}$} \\
\hline & Std Coefficient & t-value & Std Coefficient & t-value \\
\hline \multicolumn{5}{|l|}{ Characteristics of household } \\
\hline Age of household head (years) & 0.21 & $1.79 *$ & 0.11 & 0.68 \\
\hline Education of head (years) & -0.06 & 0.44 & -0.01 & -0.08 \\
\hline Received remittance $($ yes $=1$ ) & -0.01 & -0.09 & 0.25 & $1.86^{*}$ \\
\hline Engaged off-farm job (yes=1) & -0.27 & $-2.46^{* *}$ & -0.14 & -1.05 \\
\hline \multicolumn{5}{|l|}{ Characteristics of farming } \\
\hline Custom help labor (yes=1) & -0.15 & -1.42 & 0.28 & $2.22 * *$ \\
\hline Non-subsidized fertilizer $($ yes $=1$ ) & 0.03 & 0.26 & 0.42 & $3.29 * * *$ \\
\hline Applied plastic $($ yes $=1)$ & -0.36 & $3.23 * * *$ & -0.17 & -1.26 \\
\hline Seed collective buying (yes $=1$ ) & 0.41 & $3.94 * * *$ & -0.04 & -0.28 \\
\hline $\log$ of Chili Revenue & 0.11 & 0.88 & 0.07 & 0.59 \\
\hline $\mathrm{F}$ & & 5.49 & & 2.68 \\
\hline R-squared & & 0.43 & & 0.34 \\
\hline Number of observation & & 56 & & 56 \\
\hline
\end{tabular}

Note: $* * *$ Significant at $1 \%$ level, $* *$ Significant at 5\% level, * Significant at $10 \%$ level

Source: Primary Data Analysis, 2013

This study is analyze the influence of independent variable such as mentioned on Table 3 into performance of chili farmer households of collective marketing which is measured by the percentage of chili product that is sold through collective marketing of total chili product. Multiple regression from Bugel's farmer group indicate that percentage of selling on collective marketing was influenced significantly positive by age and possibility on buying seed collectively from the group while there were two variables which influenced significantly negative, off-farm job and plastic application. However, in Garongan Farmer Group was found that the percentage of selling chili to collective marketing were influenced positively by received a remittance, conducted custom help labor on harvesting period and utilizing non-subsidized fertilizer.

Even though, selling chili through collective marketing is convenient for farmers who are old and young but according to Table 3, Bugel's farmers who are old on age have a tendency to sell more percentage of their chili product on collective marketing otherwise Bugel's young farmers have a tendency to sell more percentage of chili to outside trader. Old farmers have been started chili farming and joined farmer group earlier than young farmers. The policy of receiving seed from farmer group is determined by accumulation of savings for seed from farmer on the collective marketing. Old farmers who are earlier on starting chili farming and joining farmer group gained more benefit from the group so that old farmers tend to rely on to group whenever they need. Moreover, in order to receive information from Bugel farmer group, farmers should be proactive to build an interpersonal relationship with the board, while all member of Bugel farmer group board are from old farmers around 45-54 years old. Among old farmers, they can make interpersonal communication easier rather than between old and young farmers. Young farmers are reluctant to introduce the interpersonal relationship with the board because of generation gap so that they have a possibility to missed-informed about the policy of the Bugel farmer group. Even though, high price on collective marketing has also attracted young farmer to sell on it, but young farmers who cannot receive the benefit should seek an alternative and rely on it. As a result, young farmers tend to sell less chili on collective marketing because they also should maintain the relation with the input providers who helped them to secure their chili farming activities on the next season. In the contrary, age is not the critical point to influence the percentage of selling in Garongan farmer group, because both farmers, young farmers and old farmers are able to access and receive the benefit from the group because of information is spreading up equally for every farmer through formalize meeting which is held every 35 days regarding on Javanese calendar.

The implementation of seed distribution policy, first-come first served, influenced the proportion of selling chili 
through the group because farmers who bought seed from the group have a tendency to sell more chilies through collective marketing. Farmers who did not buy a seed from the group can choose sell more chilies to collective marketing or chili traders based on their preference. Actually, Bugel farmer group has not determined a rule about percentage of chili; which should be sold through collective marketing. Farmers who bought a seed with a debt in the traders, they would sell more chili to the chili trader because of their agreement. Compared with Bugel farmer group, Garongan farmer group determined that all members possess same chance to buy seed collectively. "The more fund, the more chance to buy collective seed" has not existed on Garongan farmer group because all farmers are able to order seed, even though some larger area farmers need to buy additional seed individually because the seed from the group has limited. In Garongan village, the mechanism of buying seed on debt through input provider which should sell chili product in return has not found. As a result, all Garongan farmers prefer to sell more chili through collective marketing in order to obtain high revenue.

Among the Bugel's farmers, $34 \%$ of farmer are engaged an off-farm job such as construction labor, agriculture labor, fisherman, trader and government workers. Different with full-time farmers, off-farm job farmers are also busy to work outside farm so that it caused the probability to miss-informed about group facility such as seed collective buying. In this sense, farmers with off-farm jobs should seek the alternative ways to fulfill the needs on chili farming so that they maintain the relationship with the traders for some reasons. In addition, the off-farm job farmers have possession commute to outside village rather than full-time farmers, they have an ability find trader to cooperate and negotiate with on it. When off-farm job farmers of Bugel farmer group missed the information from the group during their absenteeism in the village, off-farm job farmers of Garongan farmer group did not face its problem. Garongan farmer group shared the equal information through reguler meeting and chance to access the group facility so that off-farm job farmers have not required on seeking third party to resort on it. In this way, collective marketing has still promised to optimize the profit for Garongan farmers while they are also should obey the regulation.

Applying plastic to cover the surface of land has been became an innovation for sandy land farmers in order to reduce cost for weeding labor and time, which is also, can increase the yield productivity. In Bugel, about $46 \%$ of farmers are using plastic to economize the labor whereas some of them tend to sell less chili to collective marketing. Among the Bugel farmers who are using plastic, more than a half are engaged an off-farm job which is means, the early adopters of innovation whose farmers who have opportunity to commute to outside village and communicate with the third party such as input traders to convince the advantages of using plastic. However, the high price of plastic forces early adopter farmers to expend amount of money for buying it, so that they should seek opportunity buying plastic through debt from input traders, which is resulted they oblige to sell chili to them whose gave a debt in return. In Garongan, only $17 \%$ farmers applied plastic to cover the surface of land, neither farmer who did not apply plastic or farmer who applied plastic, both of them sold more chilies through collective marketing. Input trader in Garongan village did not deal with chili product as well so if farmer has a debt with input trader, he should pay debt in a cash rather than chili product.

In the harvesting period, it is expected that farmers are busy on picking up the chili product in time while it cannot be conducted by only one or two farmers so that farmers should look for some labors through hiring labor or exchanging labor using traditional custom help namely sambatan. Farmer who is using hired labor for picking up chili product should prepare cash money to pay hired labor immediately. In this sense, delay payment on collective marketing becomes a constraint of holding immediate cash to pay harvesting hired labors. Some farmers who need immediate cash to pay harvesting hired labor, they tend to sell chili to sub-intermediate trader individually.Eventhough some of Garongan's farmers are able to use traditional custom help labor or sambatan in order to prevent the high cost and quick payment of hired labors but some others who possessed very large area of chili farming, they need more labors which can be obtained through hired labor instead of sambatan. The Sambatan requires equal exchange labor from every member of the group. In the case of Bugel, farmers are busy with their off-farm business so that they do not tend to choose custom help labor to substitute hired labor because it seems difficult for them to give a reciprocal aid to other farmer.

In order to encounter the quick payment problem, receiving remittance can help farmer to manage their cash flow and it is worth for Garongan farmers. As be predicted, all Garongan's farmers who received remittance, sell more chili on collective marketing because they can bear the quick payment problem for hired labor. In contrast with, receiving remittance was not a critical point of Bugel's farmer to manage fund and capital to conduct chili farming because Bugel's farmer can rely on input trader to help them whenever they need input or cash.

Besides the regulation of minimum percentage of selling chilies, Garongan's farmer also should pay attention to the quality of chili. Only good quality of chili is accepted to sell through collective marketing. The quality of chili in Garongan farmer group is classified by size and condition while in Bugel's is classified only by condition. 
The chili which is surface is not wet is regarded as a good condition. Along with the regulation of percentage and quality, Garongan's farmers have been tried to accomplish the requirement on selling through collective marketing by adding non-subsidized fertilizer to produce large chili size during the period of chili farming. Further, Garongan farmers could sell more chilies to collective marketing because they were able to control the quality of chilies. In the contrary, Bugel farmer group has not controlled the quality of chili size so that utilizing non-subsidized fertilizer could not influence the tendency of selling chili on collective marketing.

In summary, Bugel's and Garongan's farmer groups worked out a system for handling collective marketing. Both groups worked toward this, but their purposes for selling collectively were different. Garongan's farmer group has conformed to the norms as a basis of farmer behavior, not only in collective marketing, but also in other collective actions. A few farmers in Garongan who lack of cash flow to pay for labor tend to sell chili product to intermediate traders. On the contrary, a few Bugel's farmers take advantage of a good opportunity using intermediate traders. However, most of farmers realize that collective marketing is still the best plan to maximize their benefits. As a result, Bugel's farmer group also has performed well in collective marketing.

\section{Conclusion}

This study has addressed the importance consideration when comparing farmer group performance of collective chili marketing. Economic problems guide individuals to seek benefits for themselves and their families. Functioning farmer groups are a form of organization that unite farmers based on their interests and formulate collective action. This will only succeed when farmer group can create social insurance that is appropriate to their needs and environment and act according to the norms.

The findings of this study have several important managerial implications. First, chili collective marketing has proven as a beneficial market for chili farmers in Indonesia. Build the relationship with the wholesale traders resulted advantage on chili price because chili price is determined by demand and supply interactions in the wholesale markets. Even though, farmer group also should pay attention to maintain the quality and quantity of chili. Second, individual performance of farmers on the farmer group is differed by the benefit which gained from the farmer groups. Farmer group which determined to distribute the input equally, the member of farmer group does not have to seek third party to resort on it, will conform to perform selling chili collectively. On the other hand, farmer group which determined the mechanism of seeking chili input by the member individual activities, the performance of collective marketing is depend on the farmers' individual judgment. Third, the existing of routine meeting in the farmer group will encounter the missed-informed of all members of farmer group.

Since chili is produced almost all of area in Indonesia while the price of chili is determined by supply and demand in the wholesale market so that the chili over supply will drop the price. Even though farmers are not able to do something when the price drops but through build the relations with the wholesale traders least of all farmers through farmer group can get a price information and quota of chili. Through collective marketing, farmers have a bargaining position toward intermediate traders, so that farmer group especially chili farmer group in Indonesia should take a consideration to shorten a marketing chain and create a networking with a wholesale trader. As a result, collective chili marketing can be the important key factor to increase the better socio-economic condition for farmers.

\section{Acknowledgements}

The author would like to thank Professor Takenori Matsumoto, Department of Agriculture and Resource Economics, The University of Tokyo for his valuable comments and insightful reading of this manuscript. This study has been funded by the Directorate General of Higher Education (DGHE) Scholarship, Indonesia.

\section{References}

Agricultural Research Centre. (2012). Rekapitulasi Kelompok Tani dan Gabungan Kelompok Tani Per Provinsi Pusat Penyuluhan Pertanian-Badan Penyuluhan dan Pengembangan SDM Pertanian. Indonesia. Retrieved from http://bppsdmp.deptan.go.id

Anonim. (2011). Bugel and Garongan Farmer Group Report. Unpublished.

Baumann, M. R., \& Bonner, B. L. (2004). The effects of variability and expectations on utilization of member expertise and group performance. Organizational Behavior and Human Decision Processes, 93(2), 89-101. http://dx.doi.org/10.1016/j.obhdp.2003.12.004

Cecillia, N., Victor, O., Blaise, B., Omobowahe, O., \& Abayomi, O. (2009). Socio economics Factors Affecting Intensity of Market Participation among smallholders: Yam-based system farmers in Oyo North Area of 
Nigeria. International Journal of Economics Perspectives, 3(2), 131-140.

Fafchamps, M., \& Vargas-Hill, R. (2005). Selling at the Farmgate or Travelling to Market. American Journal of Agricultural Economics, 87(3). http://dx.doi.org/10.1111/j.1467-8276.2005.00758.x

Fox, \& Roger. (1979). Potentials and Pitfalls of Product Marketing through Group Action by Small Scale Farmers. Agricultural Administration. Applied Science Publishers. http://dx.doi.org/10.1016/0309-586X(79)90006-2

Giel, T. (2008). Challenge for smallholders market access: A review literature on institutional arrangement in collective marketing. Steward Postharvest Review. Retrieved from http://ssrn.com/abstract=1873268

Gordon, W. (1980). Institutional Economics: The Changing System. University of Texas Press. Austin and London.

IFAD. (2001). Rural Poverty Report 2001: The Challenge of ending rural poverty. Retrieved from http://www.ifad.org/poverty/

Lapar, M. L., Holloway, G., \& Ehui, S. (2003). Policy options promoting market participation among smallholder livestock producers: A case study from the Philippines. Food Policy, 28, 187-211. http://dx.doi.org/10.1016/S0306-9192(03)00017-4

Little, D. (2011). Western Philosophy of Social Science Lecture 9: Moral Economy Debate (PowerPoint Slide). Retrieved from http://www-personal.umd.umich.edu/ delittle/Lectures/wpss\%20lecture\%209.pdf

Mahpudin. (2011). Perkembangan Produksi dan Harga Pangan Pokok Tahun 2011 dan Prediksi Tahun 2012. Seminar Indonesia Economic Observation 2011-2012. Retrieved from http://www.docstoc.com/docs/119523828/bappenas--perkembangan-ekonomi-indonesia-dan-dunia

Markelova, H., \& Meinzein-Dick, R. (2009). Collective action for smallholder market access. CAPRI Policy Brief No 6. Retrieved from http://www.capri.cgiar.org

Popkin, S. (1980). The Rational Peasant: The Political Economy of Peasant Society. Theory and Society, 9(3). Retrieved from http://www.jstor.org/stable/656877; http://dx.doi.org/10.1007/BF00158397

Pradhan, P. (1999). Role of Institutions in Rural Community Development. Asian Productivity Organization. Tokyo.

Sahara, G. A., Stringer, R., \& Umberger, W. J. (2013). Farmer-Trader Relationships in the Indonesian Chili Markets: The Role of Relationship Quality in Modern and Traditional Supply Chains. International Food Policy Research Institute (IFPRI). Retrieved from http://ebrary.ifpri.org/cdm/ref/collection/p15738coll2/id/127974

Supriyanto, S., Herianto, S. H., Wastutiningsih, S. P., Untari, D. W., Dinarti, S. I., \& Winanti, D. L. (2012). Strategi Adaptasi Petani terhadap Perubahan Iklim. Pintal. Yogyakarta.

Wahyuni, S. (2003). Kinerja kelompok tani dalam sistem usaha tani padi dan metode pemberdayaannya. $J$. Litbang Pertanian, 22. Retrieved from http://pustaka.litbang.deptan.go.id/publikasi/p3221031.pdf

White, B., Morey, P., Natawidjaja, R., \& Morgan, W. (2007). Vegetable value chains in Eastern Indonesia-a focus on chili. Australia Centre for International Agricultural Research, Canberra. Retrieved from http://aciar.gov.au/files/node/3943/Final\%20report\%20SMAR-2007-042.pdf

\section{Copyrights}

Copyright for this article is retained by the author(s), with first publication rights granted to the journal.

This is an open-access article distributed under the terms and conditions of the Creative Commons Attribution license (http://creativecommons.org/licenses/by/3.0/). 